\title{
Monitoring Kepatuhan Peraturan Kawasan Tanpa Rokok di Lingkungan Sekolah Kota Yogyakarta
}

\author{
Heni Trisnowati ${ }^{\star}$, Utari Marlinawati \\ Program Studi Kesehatan Masyarakat, Fakultas IImu Kesehatan, Universitas Respati \\ Yogyakarta
}

*corresponding author, e-mail: hentris27@gmail.com

Recieved: 30/10/2019; Published: 11/02/2020

\begin{abstract}
Background: Smoke-Free School (SFS) policy have been implemented since 2015. These regulations include elementary schools, junior high schools, senior high schools and vocational high schools both private and public. SFS policy aims to create a clean, healthy and smoke-free school environment. Beside, SFS policy is the only effective way to protect the community (school residents) from the dangers of smoke, but the regulation has not been fully implemented by schools in the city of Yogyakarta. This study aims to describe the compliance of SFSP in schools throughout the city of Yogyakarta and the challenges of implementing these regulations. Method: This study used a quantitative method with cross-sectional survey design and observation. The population in this study were all schools in the city of Yogyakarta including elementary, middle and high school or vocational schools. Total samples were 162 schools. The sampling technique used the Proportional Stratified Random Sampling method. Data was collected through one survey and analyzed descriptively using a computer system. Results: input indicators of SFS policy: $89.5 \%$ of schools in the Yogyakarta city already have a written policy; $88.3 \%$ of schools already have promotional media about smoking bans, $66 \%$ of schools already have personnel who monitor SFS policy; Process indicators of SFS policy: $88.9 \%$ had already received SFP socialization directly. Output indicator of SFP: there are 146 (90.1\%) smoke-free schools in Yogyakarta. Barriers to the implementation of SFS policy include smoking behaviour of school residents, lack of ability to conduct assertiveness, environment and school policies have not to support SFS. Conclusion: The level of school compliance with SFS in the city of Yogyakarta is high. Socialization of SFS needs to be carried out continuously, especially for pickers (parents) and giving a strict sanction for those who violate SFS policy.
\end{abstract}

Keywords: monitoring; compliance; smoke-free school policy

Copyright $\odot 2020$ Universitas Ahmad Dahlan. All rights reserved.

\section{Pendahuluan}

Secara global terjadi peningkatan konsumsi rokok terutama di negara berkembang. Meskipun bahaya rokok sudah banyak diinformasikan tetapi jumlah perokok di Indonesia tidak menurun bahkan cenderung mengalami peningkatan. Pada tahun 2009, jumlah perokok aktif di Indonesia terbanyak ketiga di dunia setelah Tiongkok dan India. Selain itu perokok pemula semakin muda usianya.(1) Peningkatan konsumsi tembakau tertinggi terjadi pada kelompok umur paling muda yaitu 10-14 tahun dari 0,3\% tahun 1995 menjadi 3,7\% tahun 2013 atau meningkat 12 kali lipat selama 19 tahun terakhir. Selain itu, terjadi pola peningkatan perokok pada usia remaja dan produktif terutama pada kelompok umur 15-19 tahun.(1)

Penggunaan tembakau terutama merokok menjadi penyebab utama kematian secara global yang dapat dicegah.(2) Kebiasaan merokok telah membunuh lebih dari 6 juta manusia dan menyebabkan kerugian ekonomi sebesar ratusan dollar di dunia setiap tahun. Kematian paling banyak terjadi di negara-negara berkembang seperti Indonesia. Jika tren ini terus terjadi maka pada tahun 2030 penggunaan tembakau akan membunuh lebih dari 8 juta manusia di 
seluruh dunia setiap tahun dimana $80 \%$ kematian terjadi pada manusia yang tinggal di negara berkembang.(2)

Umumnya kegiatan pencegahan merokok berfokus pada remaja awal (11-14 tahun) dan remaja pertengahan (15-17 tahun) yang telah menggunakan media massa seperti sekolah dan setting masyarakat.(3) Saat ini di Indonesia sudah ada peraturan yang mengatur kawasan tanpa rokok di lingkungan sekolah yaitu peraturan menteri pendidikan dan kebudayaan nomor 64 tahun 2015.(4) Berdasarkan kebijakan tersebut idealnya semua sekolah yang ada di Indonesia sudah menerapkan kawasan tanpa rokok sejak tahun 2015. Namun realita di lapangan belum semua sekolah menerapkan secara komprehensif peraturan tersebut. Begitu pula di Kota Yogyakarta, sebagai salah satu icon kota pelajar idealnya sudah menerapkan KTR di semua sekolah mulai dari Sekolah Dasar, Sekolah Menengah Pertama dan Sekolah Menengah Atas serta Sekolah Menengah Kejuruan tetapi masih ada beberapa sekolah yang longgar terhadap aturan KTR.(5)

Kawasan Tanpa Rokok (KTR) adalah ruangan atau area yang dinyatakan dilarang untuk kegiatan merokok atau kegiatan memproduksi, menjual, mengiklankan, dan atau mempromosikan produk tembakau.(5) Kawasan Tanpa Rokok meliputi fasilitas pelayanan kesehatan, tempat proses belajar mengajar, tempat anak bermain, tempat ibadah, angkutan umum, dan tempat lain yang ditetapkan. Untuk tempat umum dan tempat kerja dapat menyediakan kawasan untuk merokok (smoking area) dan tidak diperkenankan merokok selain kawasan ini. Pemimpin atau pengelola tempat kawasan tanpa rokok bertanggung jawab memberikan informasi tentang larangan merokok dengan penandaan berupa stiker, tulisan atau tempelan lainnya disamping juga melakukan pembinaan terhadap pelaksanaan peraturan ini dilingkungan yang menjadi kewenangannya. KTR merupakan salah satu solusi menghirup udara bersih tanpa paparan asap rokok. KTR ini bertujuan untuk mengendalikan para perokok yang menghasilkan asap rokok yang sangat berbahaya bagi kesehatan perokok aktif maupun pasif.(6) Beberapa kajian tentang kawasan tanpa rokok membuktikan bahwa KTR merupakan salah satu cara yang cukup efektif dalam mengendalikan kebiasaan merokok.(3)

Sekolah merupakan salah satu kawasan tanpa rokok, karena merokok akan mengakibatkan terganggunya kegiatan belajar mengajar. KTR di sekolah bertujuan untuk menciptakan lingkungan sekolah yang bersih, sehat dan bebas rokok.(5) Pada kenyatannya banyak perokok yang masih melanggar kebijakan Kawasan Tanpa Rokok dan sering dijumpai pelanggaran di area tersebut.Beberapa guru, tenaga kependidikan bahkan kepala sekolah dengan santainya merokok di sekolah tanpa memikirkan akibat dari kebiasaan yang tidak baik tersebut. Efek dari kebiasaan itu adalah ketika para siswa yang melihatnya merasa bahwa merokok adalah hal yang wajar dilakukan. Anggapan tersebut sedikit banyak akan memberikan pengaruh bagi pelajar untuk mencoba merokok. Sebagian pelajar di Indonesia kini telah menjadi perokok aktif. $(5,7)$

Berdasarkan latar belakang yang telah diuraikan peneliti ingin mendeskripsikan kepatuhan peraturan kawasan tanpa rokok sebagai strategi melindungi masyarakat dari paparan asap rokok di lingkungan sekolah Kota Yogyakarta dan hambatan yang ditemui selama pelaksanaan peraturan tersebut. Penelitian ini bermanfaat bagi Dinas Pendidikan sebagai bahan kajian untuk evaluasi lebih lanjut tentang penerapan KTR di lingkungan sekolah dan membuat rencana aksi untuk penegakan KTR, dan bagi Puskesmas sebagai bahan masukan untuk melakukan upaya monitoring yang efektif terhadap kawasan tanpa rokok di lingkungan sekolah.

\section{Metode}

Studi ini menggunakan metode kuantitatif dengan rancangan penelitian survei potong lintang menggunakan kuesioner. Penelitian ini dilaksanakan di Lingkungan sekolah se-kota Yogyakarta pada Bulan Maret - Juli 2018. Lingkungan sekolah yang diteliti terdiri dari Sekolah Dasar, Sekolah Menengah Pertama, Sekolah Menengah Atas, dan Sekolah Menengah Kejuruan baik yang berstatus Negeri ataupun Swasta. Populasi dalam penelitian ini adalah seluruh Sekolah yang berada di Kota Yogyakarta sejumlah 298 sekolah. Dengan perincian sebagai berikut 90 SD negeri, 76 SD Swasta, 16 SMP negeri, 42 SMP Swasta, 11 SMA negeri, 32 SMA Swasta, 8 SMK Negeri dan 23 SMK Swasta. Penentuan jumlah sampel menggunakan tabel yang dikembangkan oleh Isaac dan Michael.(8) Teknik pengambilan sampel menggunakan metode " Proporsional Stratified Rondom Sampling" karena populasi 
mempunyai anggota atau unsur yang tidak homogen dan berstrata secara proporsional. Perincian jumlah sampel sebagai berikut : 49 SD negeri, 41 SD Swasta, 9 SMP negeri, 23 SMP Swasta, 6 SMA negeri, 18 SMA Swasta, 5 SMK Negeri dan 12 SMK Swasta. Total jumlah sampel menjadi 162 . Selanjutnya Indikator kepatuhan terhadap peraturan KTR di sekolah dapat dibagi menajdi indikator input, indikator proses dan indikator output seperti pada Gambar 1. di bawah ini:

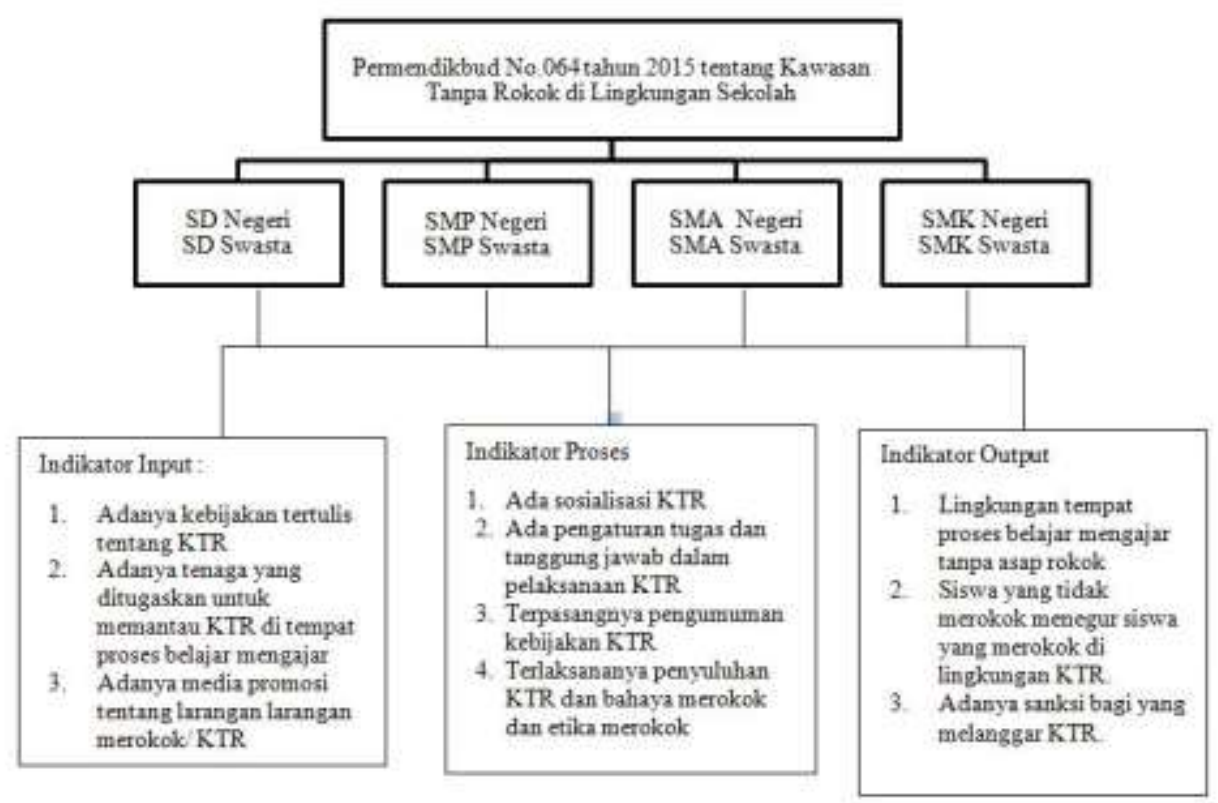

Gambar 1. Indikator Kepatuhan Peraturan Kawasan Tanpa Rokok pada Sekolah di Kota Yogyakarta

Pengumpulan data dilakukan melalui survei menggunakan kuesioner pada sekolahsekolah yang telah terpilih sebagai sampel penelitian. Setiap sekolah diwakili oleh kepala sekolah atau yang mewakili sebagai responden. Instrumen penelitian yang akan digunakan adalah kuesioner tentang tingkat kepatuhan KTR sebagai strategi melindungi masyarakat dari paparan asap rokok. Sementara itu untuk hambatan pelaksanaan KTR di sekolah disurvei dengan pertanyaan terbuka dimana responden menuliskan jawaban pada kuesioner secara bebas. Instrumen penelitian dibuat oleh berdasarkan peraturan KTR di lingkungan sekolah dan tempat belajar $(4,6)$. Analisa data kuantitatif dilakukan secara univariate untuk memperoleh deskripsi kepatuhan KTR pada sekolah, sementara data kualitatif yang diperoleh dianalisa dengan konten analisis. Penelitian ini mendapat surat keterangan kelaikan etik dari Komisi Etik Penelitian Kesehatan Fakultas IImu Kesehatan Universitas Respati Yogyakarta no.019.4/UNRIYO/PL/II/2018.

\section{Hasil dan Pembahasan}

\subsection{Hasil}

3.1.1. Gambaran Lokasi Penelitian

Berdasarkan Tabel 1. sebagian besar responden adalah Sekolah Dasar (SD) $(54,9 \%)$ diikuti SMA/SMK $(25,9 \%)$ dan SMP $(19,1 \%)$. Sementara bila dilihat dari status sekolah, Jumlah SD negeri paling banyak $(30,2 \%)$ dan yang paling sedikit adalah SMP negeri $(5,6 \%)$. Secara umum jumlah SD di kota Yogyakarta paling banyak dibandingkan SMP dan SMA/SMK hal ini berdampak pada jumlah sekolah yang menjadi sampel paling banyak adalah SD. Status sekolah swasta cenderung lebih banyak dibandingkan sekolah negeri dari semua tingkatan. 
Tabel 1. Gambaran Lokasi Penelitian

\begin{tabular}{ccccccc}
\hline \multirow{2}{*}{$\begin{array}{c}\text { Tingkat } \\
\text { Pendidikan }\end{array}$} & \multicolumn{9}{c}{ Status Sekolah } \\
\cline { 2 - 7 } & \multicolumn{2}{c}{ Negeri } & \multicolumn{2}{c}{ Swasta } & \multicolumn{2}{c}{ Total } \\
\cline { 2 - 7 } & $\mathbf{n}$ & $\%$ & $\mathbf{n}$ & $\%$ & $\mathbf{n}$ & $\%$ \\
\hline SD & 49 & 30,2 & 40 & 24,7 & 89 & 54,9 \\
SMP & 9 & 5,6 & 22 & 13,6 & 31 & 19,1 \\
SMA/SMK & 12 & 7,4 & 30 & 18,5 & 42 & 25,9 \\
\hline
\end{tabular}

3.1.2. Indikator Kepatuhan Peraturan Kawasan Tanpa Rokok Pada Lingkungan Sekolah Di Kota Yogyakarta

Indikator kepatuhan terhadap Peraturan Kawan Tanpa Rokok dibagi menjadi tiga yaitu indikator input, indikator proses dan indikator output. Pada indikator input, hasil penelitian menujukan bahwa $(89,5 \%)$ sekolah di kota Yogyakarta sudah memiliki kebijakan tertulis tentang Kawasan Tanpa Rokok (KTR) sedangkan (9,9\%) belum memiliki kebijakan tertulis KTR. Sebanyak (66\%) sekolah di Yogyakarta sudah memiliki tenaga yang ditugaskan untuk memantau KTR di sekolah dan yang belum memiliki tenaga yang ditugaskan $(33,3 \%)$. Kemudian $(88,3 \%)$ sekolah di Yogyakarta sudah memiliki media promosi tentang larangan merokok dan yang belum memiliki $(11,1 \%)$. Secara rinci terdapat pada Tabel 2.

Tabel 2. Indikator Input Kepatuhan Peraturan Kawasan Tanpa Rokok pada Sekolah di Kota Yogaykarta Tahun 2018

\begin{tabular}{|c|c|c|c|c|c|c|c|c|}
\hline \multirow[t]{2}{*}{ Pertanyaan } & \multicolumn{2}{|c|}{ Ya } & \multicolumn{2}{|c|}{ Tidak } & \multicolumn{2}{|c|}{$\begin{array}{c}\text { Tidak } \\
\text { memilih }\end{array}$} & \multicolumn{2}{|c|}{ Total } \\
\hline & $\mathbf{N}$ & $\%$ & $\mathbf{n}$ & $\%$ & $\mathbf{n}$ & $\%$ & $n$ & $\%$ \\
\hline $\begin{array}{l}\text { Apakah sudah memiliki kebijakan tertulis } \\
\text { Kawasan Tanpa Rokok (KTR)? }\end{array}$ & 145 & 89,5 & 16 & 9,9 & 1 & 0,6 & 162 & 100 \\
\hline $\begin{array}{l}\text { Apakah ada tenaga yang ditugaskan untuk } \\
\text { memantau KTR di sekolah? }\end{array}$ & 107 & 66 & 54 & 33,3 & 1 & 0,6 & 162 & 100 \\
\hline $\begin{array}{l}\text { Apakah ada media promosi tentang larangan } \\
\text { merokok (KTR) di sekolah? }\end{array}$ & 143 & 88,3 & 18 & 11,1 & 1 & 0,6 & 162 & 100 \\
\hline
\end{tabular}

Indikator proses terdapat $(88,9 \%)$ sekolah pernah mendapatkan sosialisasi kebijakan KTR secara langsung dan $(80,9 \%)$ sekolah sudah pernah ada kegiatan sosialisasi secara tidak langsung yaitu melalui media cetak atau elektronik dari pihak sekolah. Disisi lain, dari 162 sekolah (43,5\%) sekolah tidak ada pengaturan tugas maupun pun tanggung jawab dalam pelaksanaan KTR. Kemudian $(88,3 \%)$ sekolah sudah memasang tanda KTR dan $(80,9 \%)$ sekolah sudah melaksanakan penyuluhan, bahaya rokok dan etika merokok disekolah. Bentuk pengumuman kebijakan KTR berupa Poster, tanda larangan merokok, majalah dinding, surat edaran sekolah, pengeras suara, tata tertib, banner, Line, stiker, Running Text, bimbingan konseling dan surat edaran yang diberikan kepada orangtua. Detailnya dapat dilihat pada Tabel 3. 
Tabel 3. Indikator Proses Kepatuhan Peraturan Kawasan Tanpa Rokok pada Lingkungan Sekolah di Kota Yogyakarta Tahun 2018

\begin{tabular}{|c|c|c|c|c|c|c|c|c|}
\hline \multirow{2}{*}{ Pertanyaan } & \multicolumn{2}{|c|}{ Ya } & \multicolumn{2}{|c|}{ Tidak } & \multicolumn{2}{|c|}{$\begin{array}{l}\text { Tidak } \\
\text { memilih }\end{array}$} & \multicolumn{2}{|c|}{ Total } \\
\hline & $\mathbf{N}$ & $\%$ & $\mathbf{n}$ & $\%$ & $\mathbf{n}$ & $\%$ & $\mathbf{n}$ & $\%$ \\
\hline Apakah pernah ada kegiatan sosialisasi & & & & & & & & \\
\hline $\begin{array}{l}\text { kebijakan KTR secara langsung dari pihak } \\
\text { sekolah? }\end{array}$ & 144 & 88,9 & 18 & 11,1 & 0 & 0 & 162 & 100 \\
\hline Apakah pernah ada kegiatan sosialisasi & & & & & & & & \\
\hline $\begin{array}{l}\text { kebijakan KI R secara tidak langsung darı pinak } \\
\text { sekolah? }\end{array}$ & 131 & 80,9 & 30 & 18,5 & 1 & 0,6 & 162 & 100 \\
\hline $\begin{array}{l}\text { Apakah sudah ada pengaturan tugas dan } \\
\text { tanggung jawab dalam pelaksanaan (KTR) di } \\
\text { sekolah? }\end{array}$ & 89 & 55,3 & 70 & 43,5 & 2 & 1,2 & 162 & 100 \\
\hline $\begin{array}{l}\text { Apakah sudah ada pengumuman kebijakan } \\
\text { KTR di sekolah? }\end{array}$ & 153 & 94,4 & 9 & 5,6 & 0 & 0 & 162 & 100 \\
\hline $\begin{array}{l}\text { Apakah sudah terpasang tanda KTR di sekolah } \\
\text { Bapak/ibu? }\end{array}$ & 143 & 88,3 & 18 & 11,1 & 1 & 0,6 & 162 & 100 \\
\hline $\begin{array}{l}\text { Apakah sudah terlaksana penyuluhan KTR dan } \\
\text { bahaya merokok serta etika merokok di sekolah } \\
\text { Bapak/ibu? }\end{array}$ & 131 & 80,9 & 27 & 16,7 & 4 & 2,5 & 162 & 100 \\
\hline
\end{tabular}

Sementara indikator output diperoleh $(90,1 \%)$ sekolah di Kota Yogyakarta sudah bebas asap rokok. Hampir semua $(98,1 \%)$ warga sekolah menegur jika orang merokok di lingkungan sekolah. Kemudian (79.0\%) sekolah menyatakan bahwa perokok merokok di luar lingkungan sekolah dan masih ada warga sekolah yang merokok di lingkungan sekolah (17.9\%). Selain itu, $(72,8 \%)$ sekolah menyatakan bahwa ada sanksi bagi yang melanggar KTR dan yang menjawab tidak ada sanksi $(26,5 \%)$. Hal ini dapat dilihat pada Tabel 4.

Tabel 4. Indikator Output Kepatuhan Peraturan Kawasan Tanpa Rokok pada Lingkungan Sekolah di Kota Yogyakarta Tahun 2018

\begin{tabular}{|c|c|c|c|c|c|c|c|c|}
\hline \multirow[t]{2}{*}{ Pertanyaan } & \multicolumn{2}{|c|}{ Ya } & \multicolumn{2}{|c|}{ Tidak } & \multicolumn{2}{|c|}{$\begin{array}{c}\text { Tidak } \\
\text { memilih }\end{array}$} & \multicolumn{2}{|c|}{ Total } \\
\hline & $\mathbf{N}$ & $\%$ & $\mathbf{n}$ & $\%$ & $\mathbf{n}$ & $\%$ & $\mathbf{n}$ & $\%$ \\
\hline Apakah sekolah bapak/ibu bebas asap rokok? & 146 & 90,1 & 16 & 9,9 & 0 & 0 & 162 & 100 \\
\hline $\begin{array}{l}\text { Apakah warga sekolah (kepala sekolah, guru, } \\
\text { karyawan, dan siswa) yang tidak merokok } \\
\text { menegur, jika ada yang merokok dilingkungan } \\
\text { sekolah? }\end{array}$ & 159 & 98,1 & 1 & 0,6 & 2 & 1,2 & 162 & 100 \\
\hline $\begin{array}{l}\text { Apakah perokok merokok di luar lingkungan } \\
\text { sekolah? }\end{array}$ & 128 & 79 & 29 & 17,9 & 5 & 3,1 & 162 & 100 \\
\hline $\begin{array}{l}\text { Apakah ada sanksi bagi yang melanggar KTR di } \\
\text { sekolah? }\end{array}$ & 118 & 72,8 & 43 & 26,5 & 1 & 0,6 & 162 & 100 \\
\hline
\end{tabular}

\subsubsection{Hambatan Pelaksanaan Peraturan Kawasan Tanpa Rokok Pada Sekolah}

Di Kota Yogyakarta

Berdasarkan hasil penelitian dengan kuesioner terbuka ditemukan hambatanhambatan dalam pelaksanaan KTR pada sekolah di Kota Yogyakarta sebagai berikut:

1. Kebiasaan atau Perilaku merokok warga sekolah dan penjemput: ada sebagian siswa masih merokok, siswa merokok di luar sekolah sulit untuk di pantau, ada siswa yang membawa dan menggunakan rokok elektrik, ada orangtua yang membiarkan siswa merokok karena orangtuanya juga merokok, siswa merokok sembunyi-sembunyi di kamar mandi. Sementara itu masih ada orangtua atau tamu atau penjemput siswa yang merokok; masih ada pegawai/guru yang merokok. 
2. Lingkungan sekolah kurang mendukung: lokasi sekolah yang dekat dengan rumah warga dan jalan warga, sekolah kadang-kadang digunakan untuk kegiatan sosial atau masyarakat sekitar sehingga ditemukan puntung rokok dan ada warga masih merokok, pergaulan siswa dengan komunitas temannya yang sama-sama merokok, ada pekerja yang memperbaiki sekolah masih merokok di lingkungan sekolah, banyaknya pedagang di warung kecil menjual rokok sehingga siswa mudah mendapatkan atau membeli rokok tersebut, belum adanya ruang khusus bagi perokok, ada sekolah yang menyewakan ruang laboratorium, dan lapangan basket kepada pihak luar sehingga tidak terpantau secara maksimal siapa yang merokok.

3. Tidak dapat berperilaku asertif: warga sekolah yang tidak merokok merasa sungkan untuk menegur langsung, bila warga sekolah melihat ada yang merokok maka dilaporkan ke penanggung jawab dan penanggung jawab tersebut yang menegur; adanya perpedaan umur, jabatan dan sikap sehingga sungkan untuk menegur; kurangnya peran aktif masyarakat untuk KTR disekolah

4. Kebijakan sekolah kurang mendukung: belum dibuat kebijakan KTR di sekolah, belum ada tim Khusus KTR di sekolah, minimnya sosialisasi, belum terpasang tanda larangan merokok, belum ada komitmen yang kuat tentang sanksi, belum terpasangnya CCTV di sudut sekolah.

\subsection{Pembahasan}

Penerapan kawasan tanpa rokok di sekolah yang diteliti merupakan bagian program promosi kesehatan berupa regulasi atau kebijakan. Kawasan Tanpa Rokok di lingkungan sekolah mengacu pada Peraturan Menteri Pendidikan dan Kebudayaan nomor 064 tahun 2015. Tujuan diberlakukannya KTR di sekolah adalah untuk menciptakan lingkungan sekolah yang bersih, sehat dan bebas asap rokok. Selain itu dengan adanya KTR ini berarti ikut melindungi warga sekolah yang tidak merokok dari paparan asap rokok sehingga mereka tidak menjadi perokok pasif. Yang termasuk warga sekolah atau sasaran dari peraturan ini adalah a) kepala sekolah; b) guru; c) tenaga kependidikan; d) peserta didik; dan pihak lain di dalam Lingkungan sekolah.(5)

Kepatuhan sekolah terhadap penerapan KTR dapat dilihat berdasarkan tiga indikator yaitu indikator input, proses dan output. Hasil penelitian untuk Indikator input menunjukkan bahwa sebagian besar sekolah di kota Yogyakarta sudah memiliki kebijakan tertulis tentang KTR dan media promosi untuk larangan merokok. Sementara adanya petugas yang memantau KTR presentasinya paling kecil, hal ini dimungkinkan karena sekolah tidak mempunyai tenaga khusus untuk posisi tersebut namun umumnya tenaga pemantau merangkap sebagai guru Bimbingan Konseling. Penerapan KTR di sekolah merupakan suatu keharusan karena regulasi ini bertujuan untuk menciptakan lingkungan sekolah yang bersih, sehat dan bebas asap rokok.

Selanjutnya pada idikator proses, dari 6 indikator terdapat lima indikator yang persentasinya lebih dari $80 \%$ yaitu sekolah pernah mendapatkan sosialisasi kebijakan KTR secara langsung dari puskesmas, dosen atau mahasiswa yang sedang melakukan penelitian, sekolah sudah pernah ada kegiatan sosialisasi secara tidak langsung yaitu melalui media cetak atau elektronik dari pihak sekolah, sekolah sudah mempunyai pengumuman tentang KTR, sudah terpasang tanda KTR dan udah pernah mendapat sosialisasi KTR. Disisi lain, dari 162 sekolah terdapat $43,5 \%$ sekolah tidak ada pengaturan tugas maupun pun tanggung jawab dalam pelaksanaan KTR. Tidak adanya pengaturan tugas ini disebabkan kurangnya komitmen dari sebagian pemimpin sekolah di kota Yogyakarta.

Sementara untuk indikator output menunjukkan lebih dari $90 \%$ sekolah di Kota Yogyakarta sudah bebas asap rokok. Hampir semua $(98,1 \%)$ warga sekolah menegur jika orang merokok di lingkungan sekolah namun masih ada warga sekolah yang merokok di lingkungan sekolah sebanyak $17.9 \%$. Hal ini menunjukkan bahwa keadaran warga sekolah untuk tidak merokok di lingkungan sekolah tinggi $(82,1 \%)$. Selanjutnya pemberian sanksi bagi yang melanggar KTR juga diberikan oleh sebagian besar sekolah di Kota Yogyakarta. Bentuk sanksi yang diberikan berbeda-beda sesuai dengan aturan yang dibuat oleh 
sekolah. Berdasarkan ketiga indikator tersebut, sekolah-sekolah yang ada di kota Yogyakarta mempunyai kepatuhan terhadap peraturan KTR yang cenderung tinggi.

Hasil penelitian ini sejalan dengan penelitian sebelumnya yang dilakukan di Amerika dan Canada bahwa pada umumnya peraturan kawasan tanpa rokok mendapat dukungan mayoritas masyarakat termasuk orang yang merokok. Dukungan untuk aturan KTR cenderung paling tinggi pada lingkungan sekolah yaitu pada halaman sekolah $57-91 \%$, taman bermain $89-91 \%$, pintu masuk gedung 45-89\%.(9) Adanya dukungan dari pihak sekolah untuk mematuhi kebijakan KTR berdampak pada tingginya persentasi sekolah yang sudah menerapkan KTR. Sekolah bebas asap rokok merupakan upaya melindungi warga sekolah termasuk siswa dan siswi dari paparan asap rokok. Hal ini juga sesuai dengan hasil penelitian yang dilakukan pada institusi pendidikan di California menemukan bahwa adanya kebijakan kawasan tanpa rokok berhubungan dengan rendahnya paparan asap rokok pada siswa.(10)

Implementasi KTR di sekolah tidak selalu mudah karena terdapat beberapa kendala yang ditemukan seperti masih ada warga sekolah yang merokok, lingkungan sekolah kurang mendukung seperti lokasi sekolah sangat dekat dengan rumah penduduk, kemudian orang yang tidak merokok tidak dapat berperilaku asertif dan kebijakan sekolah kurang mendukung seperti belum dibuat kebijakan KTR di sekolah, belum ada tim Khusus KTR di sekolah, minimnya sosialisasi. Walaupun beberapa temuan menyatakan bahwa implementasi peraturan KTR relatif baik dan lancar misalnya hasil survei yang dilakukan pada 134 sekolah di London pada tahun 2006 dilaporkan 79\% implementasi KTR tidak menemui kendala. Walaupun begitu, terdapat tantangan seperti $19 \%$ kendala berhubungan dengan monitoring dan penguatan aksi setelah jam sekolah di halaman sekolah. 5\% hambatan sekolah berupa masih adanya staf yang merokok dan $1 \%$ karena kurang kooperatifnya anggota masyarakat. Survei lain pada guru sekolah dasar pada tahun 2008 dilaporkan bahwa adanya tingkat kepatuhan yang tinggi terhadap peraturan (89\%), sementara ketidakpatuhan disebabkan oleh perilaku merokok pada siswa, lebih dari $30 \%$ guru melihat staf lain merokok di dalam dan di luar sekolah.(11) Hambatanhambatan selama implementasi dapat digunakan sebagai kajian evaluasi untuk lebih meningkatkan kepatuhan terhadap kebijakan KTR di sekolah.

Survei kepatuhan terhadap peraturan KTR di lingkungan sekolah merupakan cara yang efektif untuk mengukur progres sekolah bebas rokok di suatu wilayah. Implementasi kebijakan sekolah bebas rokok merupakan bagian dari upaya pengendalian tembakau. Sementara pengendalian tembakau merupakan prioritas penting kesehatan masyarakat Sebagai contoh,Turki telah 20 tahun berpengalaman dalam pengendalian tembakau, prevalensi merokok di negara ini berkurang namun jumlah perokok remaja terus meningkat sehingga program edukasi dan awareness perlu dilakukan pada masyarakat, hal ini menunjukkan bahwa monitoring yang komprehensip terhadap implementasi kawasan tanpa rokok sangat perlu dilakukan.(12)

Peraturan KTR melindungi warga sekolah terutama siswa dari paparan asap rokok dan aturan ini meminimalisir anak-anak dan remaja melihat orang merokok di sekolah sehingga dan hal ini berdampak sedikitnya jumlah perokok remaja. Implementasi KTR di sekolah merupakan bagian upaya untuk mewujudkan sekolah bebas asap rokok selanjutnya sekolah bebas asap rokok merupakan komponen penting dalam program pencegahan dan pengendalian merokok pada remaja.(13) Diseminasi hasil penelitian juga diperlukan untuk meningkatkan adopsi bagi sekolah yang belum sepenuhnya melaksanakan aturan KTR.(14) Selain itu hasil penelitian ini juga dapat digunakan bagi para pengambil kebijakan untuk melakukan tindakan dengan memperkuat instrumen yang telah digunakan.(15)

Kebijakan KTR di sekolah tidak memiliki efek signifikan pada merokok setiap hari di kalangan siswa, tetapi dapat mengurangi prevalensi merokok di lingkungan sekolah. Selain itu aturan KTR ini dapat mengurangi paparan siswa untuk merokok di lingkungan sekolah dan mengurangi kemungkinan bahwa siswa mungkin mulai bereksperimen dengan merokok di sekolah. Dengan demikian, temuan ini mendukung penelitian lain yang menunjukkan bahwa kebijakan sekolah dapat berkontribusi untuk mengurangi tingkat prevalensi merokok remaja.(16) Selain itu KTR dapat mengurangi paparan second handsmoke (SHS) pada siswa-siswa yang tidak merokok. Hal ini sangat penting karena 
paparan SHS berefek negatif terhadap kesehatan remaja, termasuk remaja yang tidak pernah perokok. Tidak ada level aman dari paparan SHS sehingga penting untuk melindungi remaja di usia dini, karena data saat ini menunjukkan bahwa sekitar sepertiga dan dua per lima dari remaja yang tidak pernah merokok terpapar dengan SHS di dalam dan di luar rumah. Dengan hanya $16 \%$ dari populasi dunia yang telah menerapkan KTR secara komprehensif, maka penting bagi komunitas kesehatan masyarakat untuk meningkatkan adopsi, implementasi, dan penegakan KTR di tempat-tempat publik dan swasta sambil menerapkan larangan komprehensif pada iklan, promosi, dan industri tembakau. memasarkan produk-produk tembakau, dan mendukung pendidikan antimerokok di sekolah.(17) Disisi lain hasil riview menunjukkan bahwa sebagian besar penelitian melaporkan tidak ada perbedaan dalam prevalensi merokok siswa antara sekolah dengan KTR formal bila dibandingkan dengan sekolah tanpa kebijakan. Sehingga sebagian besar studi di sekolah dengan kebijakan yang sangat ditegakkan, larangan merokok meluas ke ruang terbuka, melibatkan guru dan termasuk sanksi untuk pelanggaran, dengan bantuan untuk berhenti bagi perokok ditambah dukungan oleh program pencegahan.(18)

Strategi penegakan KTR yang paling sering dikutip untuk keberhasilan implementasi kebijakan bebas-rokok adalah promosi kebijakan dan kegiatan peningkatan kesadaran, rambu-rambu bebas asap rokok yang jelas dan terlihat, dan penggunaan petugas penegakan hukum dan atau hukuman atau pelanggaran. Secara keseluruhan, larangan parsial kurang efektif daripada larangan total bebas asap rokok, karena larangan total bebas asap rokok lebih mungkin dipatuhi dibandingkan dengan kebijakan yang hanya memiliki pembatasan parsial.(19)

Penelitian ini memiliki keterbatasan dalam hal sampel karena tidak melibatkan siswa dan siswi sebagai responden penelitian sehingga informasi mengenai implementasi KTR di sekolah kurang komprehensip. Selanjutnya implementasi KTR secara detail perlu disampaikan misalnya area sekolah yang bebas asap rokok atau sebaliknya area yang biasa ditemukan orang merokok. Kekuatan penelitian ini adalah memberikan informasi awal tentang implementasi KTR pada lingkungan sekolah di Kota Yogyakarta beserta hambatan-hambatan yang ditemukan dilapangan sehingga dapat dimanfaatkan untuk membuat kebijakan selanjutnya yang lebih efektif dalam meningkatkan kepatuhan masyarakat dalam implementasi KTR di Sekolah.

\section{Kesimpulan}

Secara umum kepatuhan sekolah-sekolah di kota Yogyakarta terhadap regulasi KTR cenderung tinggi. Namun perlu ada peningkatan dalam pengaturan tugas dan tanggung jawab pelaksanaan KTR. Selanjutnya, hambatan pelaksanaan KTR pada sekolah berkaitan dengan perilaku merokok pada siswa dan warga sekolah lainnya, lingkungan sekolah kurang mendukung, non perokok kurang dapat berperilaku asertif dan adanya kebijakan sekolah yang kurang mendukung KTR. Sosialisasi KTR perlu terus dilakukan terutama pada penjemput (orangtua) dan perlu ada sanksi yang tegas bagi yang melanggar KTR. Kebijakan KTR secara parsial kurang efektif dibandingkan dengan larangan total bebas asap rokok, karena larangan total bebas asap rokok lebih mungkin dipatuhi dibandingkan dengan kebijakan yang hanya memiliki pembatasan parsial.

\section{Daftar Pustaka}

1. Badan Penelitian dan Pengembangan Kesehatan, Tobacco Control Support Center. Bunga rampai fakta tembakau dan permasalahannya di Indonesia, 2014. 2014.

2. WHO. WHO report on the global tobacco epidemic, 2011: warning about the dangers of tobacco. Geneva: World Health Organization; 2011.

3. Bennett BL, Deiner M, Pokhrel P. College anti-smoking policies and student smoking behavior: a review of the literature. Tob Induc Dis. 2017;15:11.

4. Permendikbud No. 064 Tahun 2015 Tentang KTR di sekolah, Jakarta.

5. Taruna Z. Implementasi Kebijakan Kawasan Tanpa Rokok di SMA Gadjah Mada Yogyakarta. Spektrum Analisis Kebijakan Pendidikan. 2016;5(6):567-577.

6. Kemenkes. Pedoman Pengembangan Kawasan Tanpa Rokok [Internet]. Jakarta: Kementerian Kesehatan Replubik Indonesia; 2011 [dikutip 27 Februari 2017]. Tersedia pada: http://www.depkes.go.id/resources/download/promosi-kesehatan/pedoman-ktr.pdf 
7. Lestari S. Implementation of regional regulation no. 5 kulon progo 2014 on no smoking area at wates distric vocational high school. Jurnal Pendidikan Kewarganegaraan dan Hukum. 2016;5(4):1-12.

8. Sugiyono. Metode Penelitian Kuantitatif Kualiattif dan $R \& D$. Bandung: Penerbit Alfabeta; 2010.

9. Thomson G, Wilson N, Collins D, Edwards R. Attitudes to smoke-free outdoor regulations in the USA and Canada: a review of 89 surveys. Tobacco Control. September 2016;25(5):506-516.

10. Fallin A, Roditis M, Glantz SA. Association of campus tobacco policies with secondhand smoke exposure, intention to smoke on campus, and attitudes about outdoor smoking restrictions. Am J Public Health. Juni 2015;105(6):1098-1100.

11. Wilson N, Oliver J, Thomson G. Ten years of a national law covering smoke-free school grounds: a brief review. Tobacco Control. 2015;1(1).

12. Bilir N. Successes and Challenges in Tobacco Control-Turkish Experience of 20 Years. Eurasian Journal of Pulmonology. 2017;19(3):119-123.

13. Agaku IT, Obadan EM, Odukoya OO, Olufajo O. Tobacco-free schools as a core component of youth tobacco prevention programs: a secondary analysis of data from 43 countries. The European Journal of Public Health. 2015;25(2):210-215.

14. Trad C, Bayly J, Saint-Fort L, Andrews M, Patel M, Sabado-Liwag M, dkk. Adoption of Tobacco- and Smoke-Free Policies in a US National Sample of Postsecondary Educational Institutions. American Journal of Public Health. 2018;108(10):1366-1369.

15. Goel S, Ravindra K, Singh RJ, Sharma D. Effective smoke-free policies in achieving a high level of compliance with smoke-free law: experiences from a district of North India. Tobacco Control. 2014;23(4):291-294.

16. Kuipers MAG, de Korte R, Soto VE, Richter M, Moor I, Rimpelä AH, dkk. School smoking policies and educational inequalities in smoking behaviour of adolescents aged 14-17 years in Europe. J Epidemiol Community Health. 2016;70(2):132-139.

17. Veeranki SP, Mamudu HM, Zheng S, John RM, Cao Y, Kioko D, dkk. Secondhand Smoke Exposure Among Never-Smoking Youth in 168 Countries. Journal of Adolescent Health. 2015;56(2):167-173.

18. Coppo A, Galanti MR, Giordano L, Buscemi D, Bremberg S, Faggiano F. School policies for preventing smoking among young people. Cochrane Tobacco Addiction Group. Cochrane Database of Systematic Reviews. 2014;10:1-32.

19. Wynne O, Guillaumier A, Twyman L, McCrabb S, Denham A, Paul C, dkk. Signs, Fines and Compliance Officers: A Systematic Review of Strategies for Enforcing Smoke-Free Policy. IJERPH. 2018;15(7):1-14. 